\title{
Determinants of Good Governance for Public Management in Cambodia
}

\author{
Phay Som \\ National University of Management, Phnom Penh, Cambodia \\ Email: phay.mef@gmail.com
}

How to cite this paper: Som, P. (2020) Determinants of Good Governance for Public Management in Cambodia. Journal of Service Science and Management, 13, 168-177.

https://doi.org/10.4236/jssm.2020.131011

Received: November 25, 2019

Accepted: February 16, 2020

Published: February 19, 2020

Copyright (c) 2020 by author(s) and Scientific Research Publishing Inc. This work is licensed under the Creative Commons Attribution International License (CC BY 4.0).

http://creativecommons.org/licenses/by/4.0/

\begin{abstract}
The purpose of this study was to determine good governance for public management in Cambodia with a focus in all Ministries. Specifically, this study sought to: 1) identify factors that might have effect on good governance based on literature reviews, 2) determine what factors influenced on good governance, 3) give a good model for evaluation on governance and finally, this study aims to give suggestion for improvement on good governance on public management and perhaps also for private management.
\end{abstract}

\section{Keywords}

Good Governance, Public Management, Cambodia TO: Good Governance, Public Management, Employee Motivation, Infrastructure Planning, Organization Compliance and Commitment, Stakeholder Engagement

\section{Introduction}

Globalization is the movement toward greater integration of capital, technology, information, interaction between people, organizations, and transaction across national borders. It offers new economic opportunities but also imposes new political and social complexities, especially on poorer countries, that governments must address in order to stimulate more equitable economic and social development [1]. Late 2007, the world economy has been experiencing one of its greatest crises since the Great Depression of the 1930s. Many of the major economies fell into recession; most developing countries have seen growth fall, although not as much as some economies in transition. Governments at both the national and subnational levels are facing huge financial constraints in fulfilling their functions and are under pressure to adapt to the new circumstances and to become more effective institutions for development in the future [2]. 
The global changes, exogenous factors and the financial crisis will likely continue to shape public administration. However, there is little consensus over whether this will lead to a deep change in practice, or merely a continued evolution of current practices. E-government and E-governance, network governance and stakeholder engagement are seen as increasingly important in shifting governance, but these have opened up new questions of accountability, transparency and trust [3]. At the same time, strategic planning, evidence-based policy-making and performance measurement and management play a very important role in public administration. Moreover, the main lessons learned from the crisis with respect to the role of public administration, not only in terms of concrete measures to strengthen and accelerate recovery in the short term, but also with regard to how countries can improve their public administration in order to best contribute to sustainable, inclusive and equitable development for all in the long term-hence the reference in the title of the note to the challenges to and opportunities for public administration [2]. The greatest current challenge is to adapt public governance to social change in the global economy. Thus the evolving role of the State needs a flexible approach in the design and implementation of public governance [4]. Another new challenging issue for new public management is ethical problem [5]. Ethics Codes try to articulate the values and principles expected of public servants when confronting unclear or ambiguous ethical circumstances and can be used as a backbone to create modern administrative systems [6]. Additionally, new public management has to face continuously great expectations of citizens, combined with the evaluation criteria of efficiency, effectiveness, economy and value [2].

This research was conducted in accordance with a research process based on the concepts of hypothetico-deductive method which has eight steps [7]. 1) Obtaining more information through literature survey. 2) Theory framework is a step in developing a theory incorporating all the relevant factors contributing to the determinant good governance for public management in Cambodia. 3) Hypothesizing was used to generate various hypotheses for testing to examine whether the theory formulated was valid or not. 4) Data collection: develop the questionnaire based on various theorized factors, to determine the good governance. 5) Data analysis: Data obtained through the questionnaire was analyzed to see what are the important factors related to good governance, how is current public management in Cambodia, what are the statistically significant factors influenced good governance. 6) Deduction: the process of arriving at conclusions by interpreting the meaning of the data analysis's results.

\section{Theoretical Foundation}

In the late 1970s and in the early 1980s, NPM emerged as a key issue on the reform agenda in many developed countries mainly in OECD countries [8] [9]. The initial focus of NPM theory was on increasing the efficiency and effectiveness of public sector institutions. The philosophical foundations of NPM with 
their emphasis on local's participation, through private sectors, have led to new organizational economics and managerialism [10] [11]. This is symbolized as a paradigm shift when the rules-driven and highly processed old management style is replaced by a new strategy "which attempts to combine modern management practices with the logic of economics, while retaining the core public values" [12]. Researchers recognized eight main elements of NPM, which are: cost effectiveness; greater transparency in service delivery resource allocation; decentralization of traditional bureaucratic institutions; management efficiency within public agencies; disaggregating public service functions from their purchase; introducing stakeholder approaches; performance based management; contractual services, performance based appraisal; and increasing emphasis on service quality, standard setting and public responsiveness [13]. All these elements of NPM, thus, have transformed the traditional role of local government management into a more active, independent and economical pattern [14]. Similarly, [15] asserted that NPM "has effectively supplanted the traditional model of public administration, and that the public sector in the future will inevitably be managerial, in both theory and practice.

Many researches have been proposed theories on the concept of financial motivation, and its role in enhancing employee's performance in every organization some of these models have been widely used and accepted by today's organizations leaders. According to [16] the vast array of motivation theories are based on differing approaches to the origins or sources of motivation. These can be energy, heredity, learning, social interaction, cognitive processes, activation of motivation, hedonism or growth motivation.

According to [17], the planning theory is characterized by the top-down and consensus-seeking approaches. Stiftel [18] further contends that the planning theory is the engine that drives the implementation of policies. This implies that the planning theory is the source from which all planning for public policy process that culminates into implementation, emanates. In light of hereof, the planning theory for public policy implementation embodies the writings about activities and practices of planners as they undertake their planning tasks for an organizational entity or function [19]. Ferreira, A., Sykes, O., \& Batey, P. [20] describe the planning theory as being a collaborative and process-oriented theory, meaning that it entails the involvement of a number of actors over protracted period of time.

In most countries today there are increasing expectations from ordinary citizens, business leaders and Civil Society that Governments will establish and deliver higher standards of ethicality and integrity in the Civil Service, agencies of government and Government itself [21]. To obtain the standard, it is required the government to enact Ethics Code, Code of Conduct, and other regulations for daily operation of each agency. Compliance-based ethics management has become the primary method of maintaining high ethical standards in governmental and non-governmental organizations.

Freeman, R. E. [22] foundational work identified the importance of the role of 
stakeholders in relationship to the organization. His initial concept is still widely accepted, definition of a stakeholder was "any group or individual who can affect or is affected by the achievement of the firm's objectives." From this definition, a model was developed showing the firm at the center of a broad range of stakeholder groups. More recent refinements show a two tiered mapping, categorizing some stakeholder groups as primary, those that "define" the business, with an outer secondary ring of players that can impact the relationships with the primary grouping [23]. Primary stakeholders include groups such as communities, customers, employees, suppliers, and financiers; secondary stakeholders include groups such as government, competitors, consumer advocate groups, social-interest groups, and media. The processes of identification of relevant stakeholders can involve formal efforts as stakeholder mapping [24]. Fassin [25] comprehensively identifies the broad range of types of complex interactions and relationships that can be captured in such mapping processes. Interestingly, Mitchell, Agle, and Wood's, [26] typology for identifying salient stakeholders, based on managerial perception of three factors-power, legitimacy, and urgency-has been quite broadly adopted. In more recent work, Mitchell, T. R., Holtom, B. C., Lee, T. W., Sablynski, C. J., \& Erez, M. [27] reaffirmed those factors as keys to identification and categorization.

\section{Hypotheses Development}

\subsection{Hypothesis 1: Employee Motivation Is Positively Significant Impact on Good Governance}

Most recently research by Kuranchie-Mensah, and Amponsah-Tawiah [28], who found that both intrinsic and extrinsic factors with particular emphasis on pay or remuneration. Good pay was identified to be the best motivating factor for employees at the mining industry. Similarly, Nyameh, J., H. Douglas [29] indicate that an employee should be promoted base on his output to service as it affect the organization, positively. In addition, Seniwoliba and Nchorbuno [30] confirm that factors that motivate worker are a central issue in employee output, without these factors workers will not give of their best and their productivity will fall. The workers generally confirmed that monetary rewards in the form of bonuses, overtime allowance were the preferred forms of motivation, and if the work place is conducive they will be motivated to work hard.

\subsection{Hypothesis 2: Infrastructure Planning Is Positively Significant Impact on Good Governance}

Public sector entities need to ensure that they are and remain fit for purpose meaning their underlying governance and staffing structures must enable them to deliver the planned services. At the same time, development of their capabilities must enable the entity to respond successfully to changing legal and policy demands, as well as to economic, political, and environmental changes and risks to achieve its intended outcomes [31].

The techniques of good governance are deeply ambiguous, on the one hand, 
they presuppose organization and/or individual as resources of government, and strengthen their self-governing capacity; as something that will increase the effectiveness of government if provided with proper guidance and direction [32].

Previous studies found that there is positive relationship between Infrastructure Planning and organization performance [31] [33] [34] [35].

\subsection{Hypothesis 3: Organization Compliance and Commitment Is Positively Significant Impact on Good Governance}

Ethics codes and codes of conduct were considered esoteric luxuries for public service only a few decades ago. Effective codes and the ethics regimes that support them are now recognized as an essential part of a modern public administration. Codes and values were the glue that holds all of these systems together. Without integrity it is impossible for public programs to be effective, much less efficient and fair [6].

The aim of regulatory reform is to increase efficiency and effectiveness and to have a better balance in delivering social and economic policies over time. Poor regulations adherence or commitment can slow responsiveness, waste resources and hamper productivity. Regulatory governance is about providing consistent and coherent rules for changing environments. Long-term planning in regulatory reform improves public sector efficiency, responsiveness and effectiveness, but short- and medium-term programs with concrete objectives can nevertheless drive the pace of reform, demonstrate results and maximize accountability [4].

\subsection{Hypothesis 4: Stakeholder Engagement Is Positively Significant Impact on Good Governance}

Most of the time civil society organizations usually seek to identify people wants and needs in order to establish their mission. This activity emerges the concept of participation in managing local government work and develop common goal. The importance of local government stems from its increasing role in local development and services. In this regard, successful local development has been identified as essential to meet the people goals. This includes methods of empowering local authorities and promoting citizen awareness of local affairs in order to foster transparency, accountability and responsiveness of local authorities, and in turn, increase citizen satisfaction with municipal performance and outcomes.

\subsection{Hypothesis 5: Stakeholder Engagement Is Positively Significant Impact on Organization Compliance and Commitment}

A main finding of the World Bank Learning Group on Participatory Development is that "there is significant evidence that participation can, in many circumstances, improve the quality, effectiveness and sustainability of projects, and strengthen ownership and commitment of government and stakeholders [36]. 


\section{Methodology}

The research methodology and methods for this research were chosen in order to successfully achieve the research objectives. The rationale will be discussed and explaining in terms of research process, design, development of the instrument, pilot study, population, sample and data collection, data analysis, and data management of multivariate analysis. The development of the relevant instrument with the outline of problems in the survey will be discussed.

\section{Methods}

Method is an approach of conducting a research work which is determined by the nature of the problem [37]. The survey method is concerned with the present and attempts to determine the status of the phenomena under investigation. The survey method currently is the most popular one in conduct research [37]. Therefore, the current study employs a survey method, that consists of descriptive and hypotheses testing.

\section{Results}

The research framework consists of three exogenous and two endogenous variables. Each construct showed Cronbach alpha reaching acceptable values of above 0.60 [38]. The composite reliability also showed exceptionally high values of above 0.80 . The mean of each variable ranges from 4.61 to 5.06 (See Table 1).

The Stakeholder Engagement has the lowest mean (4.61) and the highest is Infrastructure Planning (5.06). It is also noted that the initial construct reliabilities (CR) range from $80.38 \%$ to $83.66 \%$ (See Table 1 ).

Loading factors of each item of the five. It is observed that the factor loadings of all items are highly adequate. Those factor loadings range from 0.63 to 0.81 . According to Hair et al. (2006), standardize regression weights of observed variable or the factor loadings should be above 0.50 . Table 2 indicates that most of the constructs confirm to the convergent validity test, and those factor loadings can be used to estimate construct reliabilities (CR) and variance extracted (VE). Notably, among the 14 deleted items, which include Employee Motivation (5 items), Stakeholder Engagement (3 items) and Good Governance (6 items) leaving a final CFA.

Table 1. Mean (Std. Dev), Cron.'s Alpha, CR.

\begin{tabular}{cccc}
\hline Variable Name & Mean (Std. Dev) & Cron.'s Alpha & CR \\
\hline Employee Motivation & $4.97(0.793)$ & $83.2 \%$ & $83.66 \%$ \\
Infrastructure Planning & $5.06(0.838)$ & $80.1 \%$ & $80.19 \%$ \\
Stakeholder Engagement & $4.61(0.865)$ & $78.3 \%$ & $80.42 \%$ \\
Organization Compliance and Commitment & $5.03(0.857)$ & $80.3 \%$ & $80.38 \%$ \\
Good Governance & $4.95(0.835)$ & $81.0 \%$ & $82.99 \%$ \\
\hline
\end{tabular}


Table 2. Final CFA of the five construct variables.

\begin{tabular}{|c|c|c|c|c|c|c|}
\hline Variable & Code & $\begin{array}{c}\text { Factor } \\
\text { Loading }\end{array}$ & SMC & Error & $\begin{array}{l}\text { Variance } \\
\text { Extracted }\end{array}$ & CR \\
\hline \multirow{4}{*}{$\begin{array}{l}\text { Employee } \\
\text { Motivation }\end{array}$} & EM3 & 0.71 & 0.504 & 0.496 & 0.501 & 0.800 \\
\hline & EM4 & 0.72 & 0.518 & 0.482 & & \\
\hline & EM6 & 0.65 & 0.422 & 0.578 & & \\
\hline & EM9 & 0.75 & 0.562 & 0.437 & & \\
\hline \multirow{4}{*}{$\begin{array}{l}\text { Infrastructure } \\
\text { Planning }\end{array}$} & IP1 & 0.74 & 0.547 & 0.452 & 0.506 & 0.803 \\
\hline & IP2 & 0.71 & 0.504 & 0.495 & & \\
\hline & IP3 & 0.76 & 0.577 & 0.422 & & \\
\hline & IP4 & 0.63 & 0.396 & 0.603 & & \\
\hline \multirow{4}{*}{$\begin{array}{l}\text { Organization } \\
\text { Compliance } \\
\text { and } \\
\text { Commitment }\end{array}$} & OCC1 & 0.73 & 0.532 & 0.467 & 0.504 & 0.802 \\
\hline & OCC2 & 0.69 & 0.476 & 0.523 & & \\
\hline & OCC3 & 0.71 & 0.504 & 0.495 & & \\
\hline & OCC4 & 0.71 & 0.504 & 0.495 & & \\
\hline \multirow{4}{*}{$\begin{array}{l}\text { Stakeholder } \\
\text { Engagement }\end{array}$} & SE1 & 0.74 & 0.547 & 0.452 & 0.540 & 0.823 \\
\hline & SE2 & 0.79 & 0.624 & 0.375 & & \\
\hline & SE5 & 0.77 & 0.592 & 0.407 & & \\
\hline & SE6 & 0.63 & 0.396 & 0.603 & & \\
\hline \multirow{4}{*}{$\begin{array}{c}\text { Good } \\
\text { Governance }\end{array}$} & GG1 & 0.68 & 0.462 & 0.537 & 0.528 & 0.816 \\
\hline & GG2 & 0.71 & 0.504 & 0.495 & & \\
\hline & GG4 & 0.81 & 0.656 & 0.343 & & \\
\hline & GG6 & 0.70 & 0.49 & 0.51 & & \\
\hline
\end{tabular}

\section{Conclusions}

The purpose of this study is to identify factors that might have effect on good governance, and aims to determine the factors influenced on good governance, get a good model for evaluation on governance and give suggestion for improvement on good governance for public management and perhaps also for private management in Cambodia.

- Firstly, the research model was established by combination several theories such as motivation, planning, stakeholder, organizational commitment and compliance, and monitoring theories as theoretical research framework.

- Secondly, the study also found that the current good governance for civil servant in Cambodia is directly driven by infrastructure planning, Organization compliance and commitment and stakeholder engagement.

- Thirdly, the study is intended to investigate of moderating effect of five categorical variables, which include gender, job level, work experience, education and oversight. The results indicate that the effect of each variable-employee motivation, infrastructure planning, organization compliance and commitment, and stakeholder engagement on good governance depend on different 
groups of people related to gender (male and female), job level (staff and management), work experience (junior and senior), education (graduate school and after graduate school), and oversight (rarely and often).

\section{Conflicts of Interest}

The author declares no conflicts of interest regarding the publication of this paper.

\section{References}

[1] Sabino, C., Savino, M., Shabbir Cheema, G., Katorobo, J., Ghaus-Pasha, A., Paul, S., Pope, J., Rizvi, G., Rondinelli, D.A., Satterthwaite, D., Szeremeta, J., Kerby, R. and Tommasoli, M. (2007) Public Administration and Democratic Governance: Governments Serving Citizens. 7 th Global Forum on Reinventing Government Building Trust in Government, Vienna, Austria, 26-29 June 2007.

[2] UN (2010) Challenges to and Opportunities for Public Administration in the Context of the Financial and Economic Crisis. Committee of Experts on Public Administration, Economic and Social Council.

[3] Curry, D. (2014) Rends for the Future of Public Sector Reform: A Critical Review of Future-Looking Research in Public Administration.

[4] OECD (2011) Policy Framework for Investment User's Toolkit.

[5] Bilhim, J. and Neves, B. (2005) New Ethical Challenges in a Changing Public Administration.

[6] Gilman, S.C. (2005) Ethics Codes and Codes of Conduct as Tools for Promoting an Ethical and Professional Public Service: Comparative Successes and Lessons. The PREM, the World Bank, Washington DC.

[7] Sekaran, U. (2003) Research Methods for Business: A Skill-Building Approach. 4th Edition, John Wiley \& Sons, Inc., New York.

[8] Hood, C. (1991) Stabilization and Cutbacks: A Catastrophe for Government Growth Theory? Journal of Theoretical Politics, 3, 37-63.

https://doi.org/10.1177/0951692891003001004

[9] Parker, L. and Gould, G. (1999) Changing Public Sector Accountability: Critiquing New Directions. Accounting Forum, 23, 109-135.

[10] Navarra, D.D. and Cornford, T. (2005) ICT, Innovation and Public Management: Governance, Models and Alternatives for eGovernment Infrastructure. ECIS 2005 Proceedings, 121. http://aisel.aisnet.org/ecis2005/121

[11] Pollitt, C. (1995) Justification by Works or by Faith? Evaluating the New Public Management. Evaluation, 9, 133-154. https://doi.org/10.1177/135638909500100202

[12] OECD (1998) Best Practice Guidelines for User Charging for Government Services, PUMA Policy Brief. OECD, Paris.

[13] McCourt, W. (2002) New Public Management in Developing Countries. In: McLaughlin, K. and Osborne, S., Eds., The New Public Management: Current Trends and Future Prospects, Routledge, London.

[14] Dollery, B. (2003) A Critical Evaluation of Virtual Local Government in Australia', Australian Journal of Public Administration, 62, 82-91. https://doi.org/10.1046/j.1467-8500.2003.00340.x

[15] Hughes, O.E. (1998) Public Management and Administration: An Introduction. 2nd 
Edition, Palgrave Macmillan, New York. https://doi.org/10.1007/978-1-349-26896-2 3

[16] Petri, H.L. (1996) Motivation: Theory, Research and Applications. 4th Edition, Brooks/Cole Publishing Company, New York.

[17] Fainstein, S.S. (2000) New Directions in Planning Theory. Urban Affairs Review, 35, 451-478. https://doi.org/10.1177/107808740003500401

[18] Stiftel, B. (2000) Planning Theory. The National AICP Examination Preparation Course Guide Book 2000. AICP, Washington DC.

[19] Watson, V. (2003) Conflicting Rationalities: Implications for Planning Theory and Ethics. Planning Theory and Practice, 4, 395-408. https://doi.org/10.1080/1464935032000146318

[20] Ferreira, A., Sykes, O. and Batey, P. (2009) Planning Theory or Planning Theories? The Hydra Model and Its Implications for Planning Education. Journal for Education in the Build Environment, 4, 29-54. https://doi.org/10.11120/jebe.2009.04020029

[21] Whitton, H. (2001) Implementing Effective Ethics Standards in Government and the Civil Service.

[22] Freeman, R.E. (1984) Strategic Management: A Stakeholder Approach. Pitman, Boston, MA, 46.

[23] Freeman, R.E., Harrison, J.S. and Wicks, A.C. (2007) Managing for Stakeholders: Survival, Reputation, and Success. Yale University Press, New Haven.

[24] Bourne, L. and Walker, D.H.T. (2006) Using Visualizing Tool to Study Stakeholder Influence-Two Australian Example. Project Management Journal, 37, 5-21. https://doi.org/10.1177/875697280603700102

[25] Fassin, Y. (2008) Imperfections and Shortcomings of the Stakeholder Model's Graphical Representation. Journal of Business Ethics, 80, 879-888.

https://doi.org/10.1007/s10551-007-9474-5

[26] Mitchell, R.K., Agle, B.R. and Wood, D.J. (1997) Toward a Theory of Stakeholder Identification and Salience: Defining the Principle of Who and What Really Counts. Academy of Management Review, 22, 853-886. https://doi.org/10.5465/amr.1997.9711022105

[27] Mitchell, T.R., Holtom, B.C., Lee, T.W., Sablynski, C.J. and Erez, M. (2001) Why People Stay: Using Job Embeddedness to Predict Voluntary Turnover (Electronic Version). Academy of Management Journal, 44, 1102-1121. https://doi.org/10.5465/3069391

[28] Kuranchie-Mensah, E.B. and Amponsah-Tawiah, K. (2016) Employee Motivation and Work Performance: A Comparative Study of Mining Companies in Ghana. Journal of Industrial Engineering and Management, 9, 255-309. https://doi.org/10.3926/jiem.1530

[29] Nyameh, J. and Douglas, H. (2013) Do Motivation Drive Employee's Performance in Public Sector Organization? European Journal of Business and Management, 5, 2222-2839.

[30] Seniwoliba, A.J. and Nchorbuno, A.D. (2013) Examining the Role of Motivation on Employee Performance in the Public Sector in Ghana. Merit Research Journal of Education and Review, 1, 23.

[31] CIPFA (2013) Good Governance in the Public Sector-Consultation Draft for an International Framework. CIPFA.

[32] Bang, H. and Anders, E. (2013) A Systems Theory of Good Governance. ICPP, 
Grenoble.

[33] Jennex, M.E. and Olfman, L. (2004) Modeling Knowledge Management Success. Conference on Information Science and Technology Management, CISTM.

[34] Probst, G., Raub, S. and Romhardt, K. (1999) Managing Knowledge: Building Blocks for Success. John Wiley, New York.

[35] Reinhardt, R. (2001) Knowledge Management: From Theory to Practice. In: Morey, D., May-Bury, M., Thuraisingham, B. and Thuraisingham, S., Eds., Knowledge Management: Classic and Contemporary Works, MIT Press, Cambridge, MA, 187-222.

[36] OECD (1997) Evaluation of Programs Promoting Participatory Development and Good Governance: Synthesis Report. Developing Assistance Committee, Paris.

[37] Singh, K.Y. (2006) Fundamental of Research. New Age International Publishers Ltd., New Delhi.

[38] Nunnally, J.C (1970) Introduction to Psychological Measurement. McGraw-Hill, New York. 